Limnological Review (2011) 11, 3: 123-132

DOI 10.2478/v10194-011-0034-0

\title{
Natural and economic factors of shrinkage of lakes of the Wielkopolska Lakeland
}

\author{
Bogumił Nowak ${ }^{1}$, Barbara Brodzińska², Izabela Gezella-Nowak \\ ${ }^{1}$ Adam Mickiewicz University in Poznań, Institute of Geology, Maków Polnych 16, 61-606 Poznań, Poland; e-mail: rugosa@op.pl \\ ${ }^{2}$ Institute of Meteorology and Water Management - National Research Institute, Poznań Branch, Dąbrowskiego 174/176, \\ 60-594 Poznań, Poland; e-mail: barbara.brodzinska@imgw.pl
}

\begin{abstract}
The paper discusses the issue of plant overgrowth in the littoral zone of lakes. It presents the plant encroachment process and its environmental and economic consequences based on the example of selected lakes of the Wielkopolska Lakeland. In order to estimate changes of quantity in the riparian vegetation structure, historical records of changes of reed bed areas were compared with their present areas. Historical data included bathymetric plans from the 1960's created by the Institute of Inland Fisheries and information obtained from interviews with the inhabitants of settlements located in the vicinity of the studied lakes. Present-day boundaries of reed bed zones were identified using orthophotos, aerial photographs and in situ inspections. In the course of the field research, identification of plant species and estimates of plant condition in the studied stands were carried out. Obtained data combined with data on local hydrological-meteorological conditions, water quality and land use in the direct vicinity of lakes allowed the authors to determine the conditioning factors of riparian vegetation encroachment. The collected evidence allowed the authors to establish that in the last five decades, the area of reed beds around the studied lakes increased by an average of $15-20 \%$. This process was usually accompanied by the encroachment of hydrophytic plants consequently leading to the shrinkage of supralittoral zones. In the last 20 years, these two phenomena intensified considerably, particularly during two low water periods noted during this period. However, the encroachment of riparian vegetation proceeded differently in the case of each lake and it was most protrusive in highly eutrophicated reservoirs and those with a history of permanent or long-term lowering of the water table. The qualitative structure of the studied plant communities was conditioned mostly by nutrient inflow and the type of growing medium. In large clean lakes and in zones of sandy lake bottom, the reed beds were dominated by the common reed (Phragmitetum australis). In smaller, polluted lakes and shielded bays of larger lakes with stagnant water, beside multi-species reed beds, floating-leaf hydrophytic macrophyte plants of the genus Nymphaea, tall stands of sedges and helophytes were observed.
\end{abstract}

Key words: plant overgrowth in lakes, Wielkopolska Lakeland, reed bed, riparian vegetation, littoral zone

\section{Introduction}

Vegetation succession in lakes, a natural process leading to the systematic shrinkage of water reservoirs, while increasing the area occupied by riparian plants, is usually perceived as a positive process. New areas of reed bed, hydrophytic trees and scrub-shrub plants create conditions for the development of a rich riparian ecosystem that provides perfect breeding sites for, among others, birds. Such areas also increase the selfpurification ability of reservoirs. Unfortunately, excessive growth of aquatic plants may have negative effects especially in areas under strong impact of anthropo- pressure (tourism, access to beaches). Stagnant water surrounding reed beds attracts burdensome insects, while decaying organic matter suspended between reed stems becomes a source of unpleasant odours. The encroachment of riparian vegetation into reservoirs also diminishes the space for fish, especially the species preferring deep, open water. These problems justify and require further research of mechanisms that influence and shape processes of riparian vegetation growth in the lakes of the Wielkopolska region. Furthermore, it is important to determine whether these riparian plants impact the environment and if so what are its consequences. 


\section{Study area}

The area of study comprises the Wielkopolska Lakeland (Kondracki 2009) as the area most familiar to the research team and, at the same time, the area that has undergone the deepest transformation in Poland. In order to obtain the best possible results reflecting conditions characteristic for different reservoir groups, twelve lakes from various parts of the Lakeland were chosen: Biskupińskie, Chrzypskie, Jarosławieckie, Kierskie, Konin, Lednica, Lubikowskie, Orchowskie, Ostrowskie, Powidzkie, Słowikowo, Witobelskie (Fig. 1). Their selection was determined by factors such as lake age, hydrological regime, climate conditions, weather conditions, land use within catchments, degree of anthropopressure, and water quality. These lakes were designated as the primary objects. In order to collect more data, reservoirs located near the primary objects were also included in the observation which, however, was less detailed. This subsidiary study contributed a considerable amount of information and allowed us to correct the theses regarding the group of our designated primary lakes.

\section{Methods}

The first task of the project was to investigate the changes in riparian plant communities in earlier years. Maps and bathymetric chart data cards produced by the Institute of Inland Fisheries in the 1960's were used as the starting point as well as maps, aerial photographs and available research papers on the subject. In order to determine the hydrological regime of lakes and climate conditions of the studied region, the data provided by the Institute of Meteorology and Water Management National Research Institute were used. The source of information concerning water quality of the lakes was Reports on the state of the environment published by the Voivodeship Inspectorates for Environmental Protection in Poznan, Bydgoszcz and Zielona Gora [WIOŚ 2011a,b,c].

The availability of source materials determined the choice of the reservoirs with the best documentation regarding the researched process. Historical data were compared with contemporary data from satellite images and recent maps. Verification of information collected during the preliminary research was performed during field trips to all studied lakes.

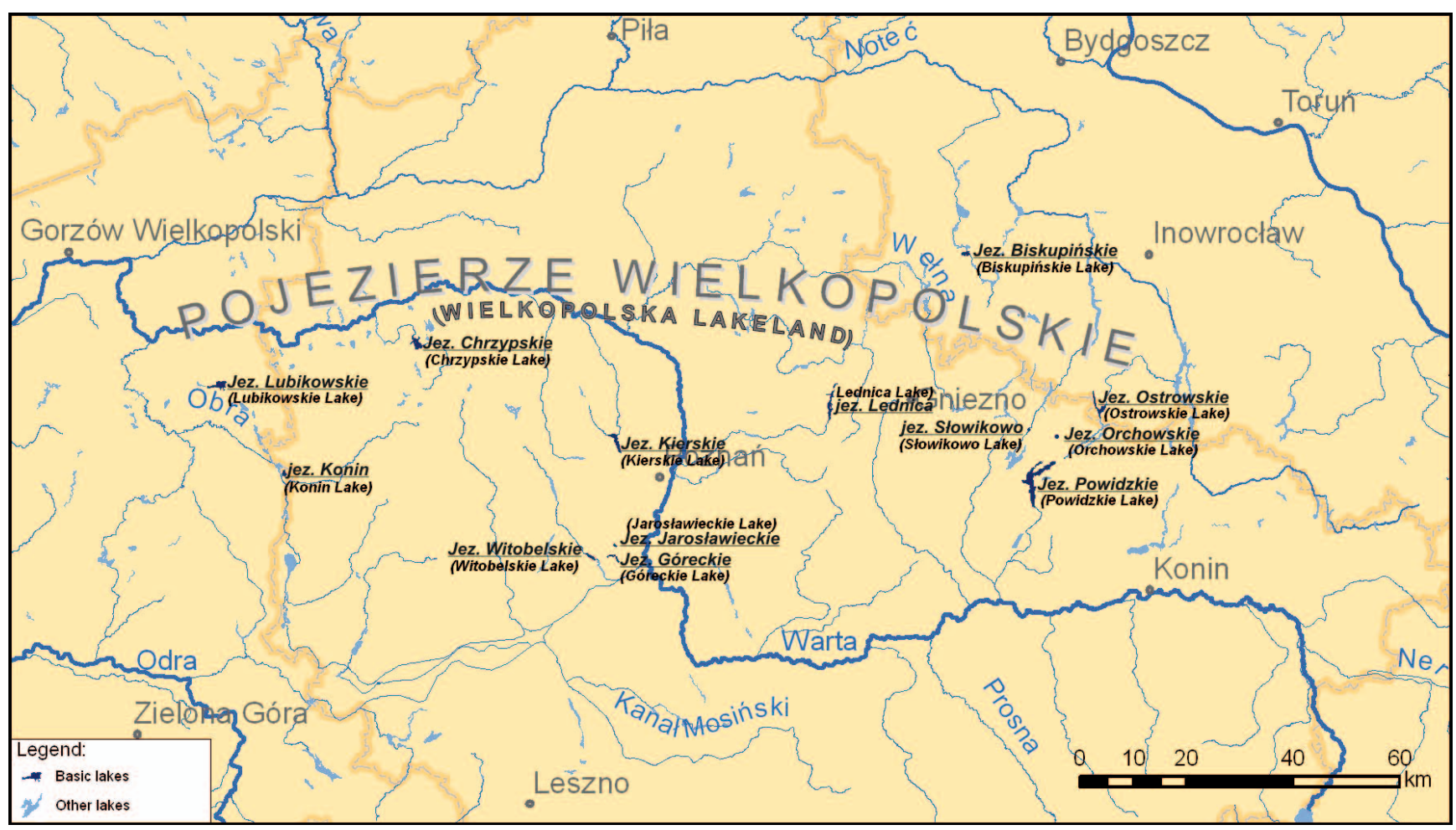

Fig. 1. Localizations of the studied lakes in the Wielkopolska Lakeland 
Field work consisted in making a detailed inventory of the riparian vegetation including determination of reed bed areas with the particular attention on the youngest growth, identification of plant species and condition of plant communities. Measurements of riparian vegetation extent into lakes were carried out both from a boat and land using measuring tape, surveying instruments and GPS. The data were marked on the topographic map (1:10000). At the same time, photographic documentation of the studied zones was made. Qualitative features such as condition, species composition and size of plant populations were determined using the method based on available literature (Grau et al. 1998; Kłosowski and Kłosowski 2006; Matuszkiewicz 2008). The observations were supplemented by interviews with inhabitants of the studied area. Further work included processing the collected raw data, creation of maps, graphs and tables illustrating the results.

The Latin plant names are based on Guide to identification of vascular plants of Polish lowlands (Rutkowski 2008).

\section{Results and Discussion}

Observations of the lakes in the Wielkopolska Lakeland allowed us to distinguish several patterns characterizing the process of reservoir shrinkage. The excessive growth of riparian plants was most advanced on the lakes located in the southern parts of the Wielkopolska Lakeland, i.e. the zone of the maximum extent of the last glacial period. It is the area covered by the largest number of shallow lakes characterized by low retention and the highest pollution. However, fast encroachment of riparian plants into reservoirs can be observed throughout the entire studied area, which is indicated by the high eutrophication of the majority of lakes.

The analysed lakes have been under very strong environmental pressure for centuries. The Wielkopolska and Kujawy regions have been under very intensive agricultural cultivation since the beginning of human settlement in Poland. In order to acquire more land for cultivation, woodlands have been grubbed up and wetlands drained. These actions led to decreased water holding capacity of the land. Prussian land improvements as well as land improvements introduced in the second half of the $20^{\text {th }}$ century, when projects favoured extensive drainage ditches, proved to have particularly negative consequences. As a result, all excess water was quickly directed outside the catch- ments. Groundwater levels dropped followed by the lowering of water tables in lakes. Since, overall, these reservoirs are not very deep and many of them have extensive shallow water zones, the lowering of water levels uncovered large areas of land, which proved to be a perfect space for the expansion of riparian vegetation. This process intensified at the beginning of the 1990's when due to a few years of low flow, water tables dropped to unprecedented lows. During this period, a dramatic expansion of riparian vegetation towards open water was observed in all reservoirs. This process is clearly visible in a comparison of the extent of reed beds and other riparian plant covered areas shown on bathymetric maps from the 1950's and 1960's [IRS 1958a,b, 1959, 1960a,b, 1962, 1964, 1968] and 1980's [IMGW 1981a,b, 1984a,b], i.e. the time of creating bathymetric plans and the present day extents as shown on our maps. The area covered by reed beds and the total quantity of riparian vegetation can be determined only after it is marked on maps. The best estimate, however, is based on in the field inspection, which provides evidence for plant expansion.

Water law defines the shoreline of natural watercourses, lakes and other natural water bodies as the edge line of the shore or as the line of permanent grass growth or a line determined according to the average water stage of the last 10 years (Dz.U.2005.239.2019). Legal regulations aside, the long stability of a shoreline is of prime importance for the littoral zone of lakes. Average water levels of lakes are written down in the form of a morphological border, i.e. lacustrine terraces. They can be clearly seen when the reservoir water level starts to lower. Each of these terraces is usually covered by hydrophytic trees such as alders and willows composing Alnetum glutinosae communities. Trees of a given age, therefore, indicate the extent of a lake at a given time. If shorelines fluctuated only slightly throughout the years, we would identify only one terrace, which would be covered by old and tall trees or scrub-shrub plants that separate reed beds from typical land plants. However, in the case of all the lakes in Wielkopolska, we observed that in front of the line of tall trees on the water-side, in the reed bed zone, there are communities of dispersed trees and shrubs. They can be divided into two groups of populations of different age (Fig. 2).

The first group - with older specimens - covers the more elevated zone and is over fifteen years old. It is composed mostly of densely packed communities of Grey Willows (Salix cinerea), alders (Al- 


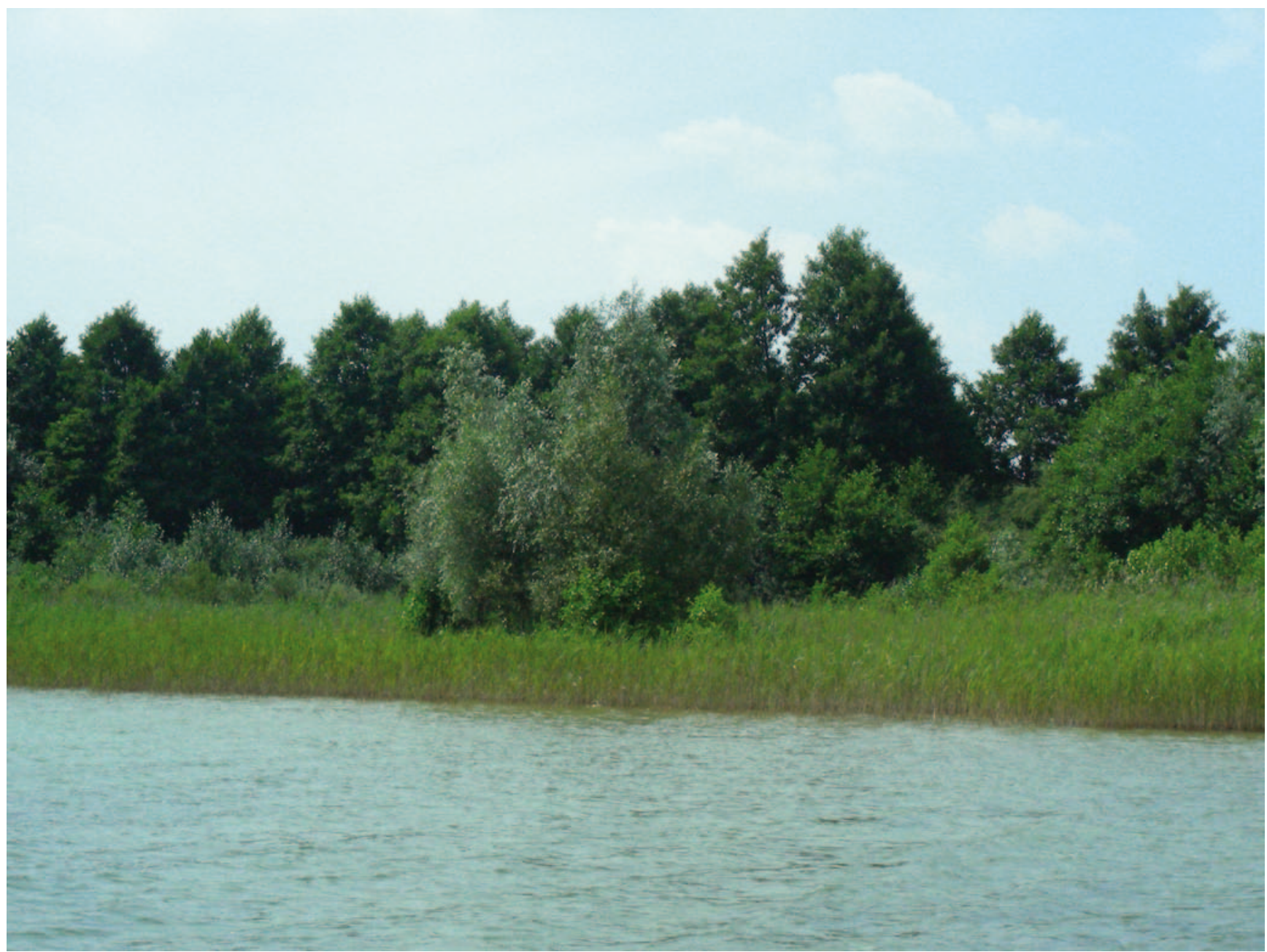

Fig. 2. Trees and shrubs in the littoral zone of Lake Powidzkie - plant expansion due to low water periods

nus) but also, and quite often, of birches (Betula) and pines (Pinus). The second group, of about five years of age, consists mostly of common osiers (Salix viminalis) and small alders in a much worse condition (Fig. 2). Hydrographs of water stages of the Wielkopolska lakes (Fig. 3) indicate that the growth of these plants coincides with periods of low flows during which water stages were lower than the long-term means even by several tens of centimetres. The early years of the 1990's were especially difficult with the highest extreme values noted. This period was followed by wet years and the process of declining water tables in lakes was arrested. The excess water, however, was not high enough to disturb the growth of young trees. Water resources in lake catchments were not restored to the levels allowing the reservoirs to reclaim their status from before the dry period. Consequently, the next dry period of 2003-2005, although not as severe as the previous one, contributed, in many locations, to an even further decline in water levels. Water receded uncovering new parts of land, which was colonized mostly by willows. Still, the last wet years have brought a systematic rise in water levels and as a result these young trees are being flooded and are consequently declining. These zones, therefore, are becoming the allochthonous source of nutrients for lakes and the inundated vegetation, which is not resistant to prolonged immersion in water, starts to decay, producing the unpleasant odour of hydrogen sulphide.

The fluctuations in the water level causing changes to the lakeshore line have also had a strong impact on reed bed plants. Without exception, the areas occupied by reed beds, especially the common reed, have increased in all of the observed lakes. In situ observations, the analysis of orthophotos and interviews with the locals indicate that there has been a 


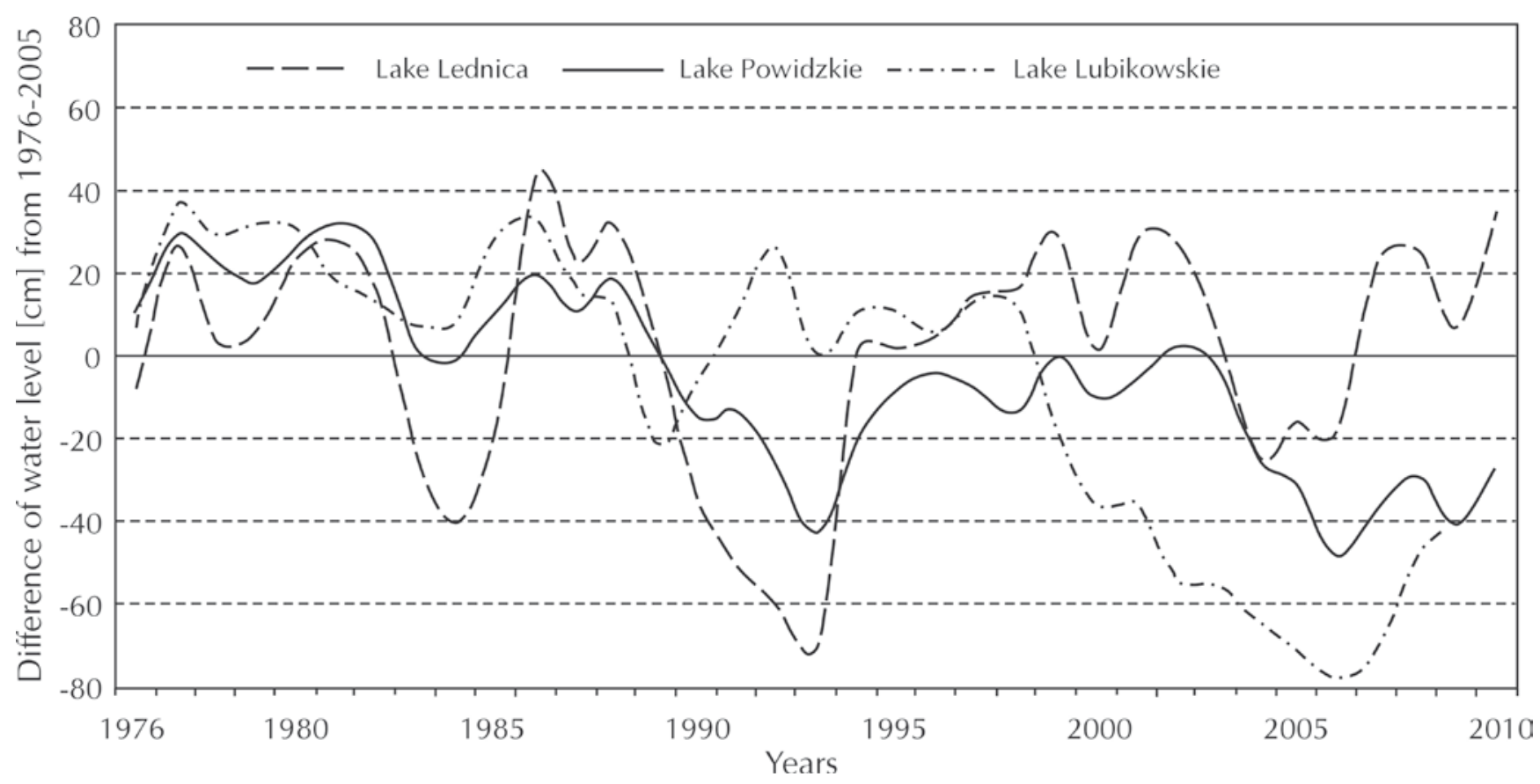

Fig. 3. Difference of mean annual water level from the long-term norm (1976-2005) in selected lakes of the Wielkopolska Lakeland (IMGW-PIB Poznań data)

visible development of reed beds in all reservoirs of the Wielkopolska Lakeland. The area occupied by reed beds increased by $15-20 \%$ on average during the studied period. Naturally, this tendency was not equally distributed and in the case of some lakes, especially those with steeply sloped littoral zones or regulated by weirs on the lake outflows, it was much weaker. The expansion of reed beds in the littoral zone accelerated particularly in the early 1990's when, as a result of several-year-long low water stages, large parts of littoral zones were exposed. These areas were quickly colonized mostly by the common reed (Phragmites australis), which because of the very well-developed root system and stout rhizomes have the best predispositions to spread over the exposed shallows. In many places, especially within wide shallows, this proved to be a very successful expansion. The width of the common reed (Phragmites australis) belt increased there by as much as several tens of metres. The appearance of these reed beds, however, differs considerably from the old growths located in shallower littoral zones. The new reed stems are much smaller in height, the plants failed to create compacted colonies and appear to be generally weaker (Fig. 4). This is probably the effect of a fast expansion onto a soil low in organic matter because of the waves splashing and washing out organic particles. Also, the increase in water level that occurred at a later time contributed to the plant regress since the young reeds, which did not grow in a compact pattern, were exposed to waves which were washing out the soil anchoring the reed roots. Nevertheless, the period hindering reed bed expansion was short as it was succeeded by another low water cycle resulting in an even larger water reduction than that in the 1990's. As the result, the existing common reed colonies expanded and, in some extreme cases, a new wave of expansion of riparian plants occurred.

The process of riparian vegetation expansion is also dependent, to a very high degree, on the type of lake, i.e. if it is a flow-through lake or if it is dammed up. Vegetation encroachment inward from the shoreline was definitely less aggressive in the case of flowthrough lakes, where river inflow is a significant recharge element. Such lakes can replenish water losses they suffered during dry years at a much faster rate and therefore their shores do not remain exposed long enough to be colonized by vegetation. Lakes located in the source sections of rivers do not have this advantage. Expanding vegetation is not stopped by seasonal flooding of the colonized area and therefore nothing hinders its development. Also weirs located at lake's outflows contribute to the lowering of the amplitude of water level fluctuations thus limiting riparian vegetation encroachment. 


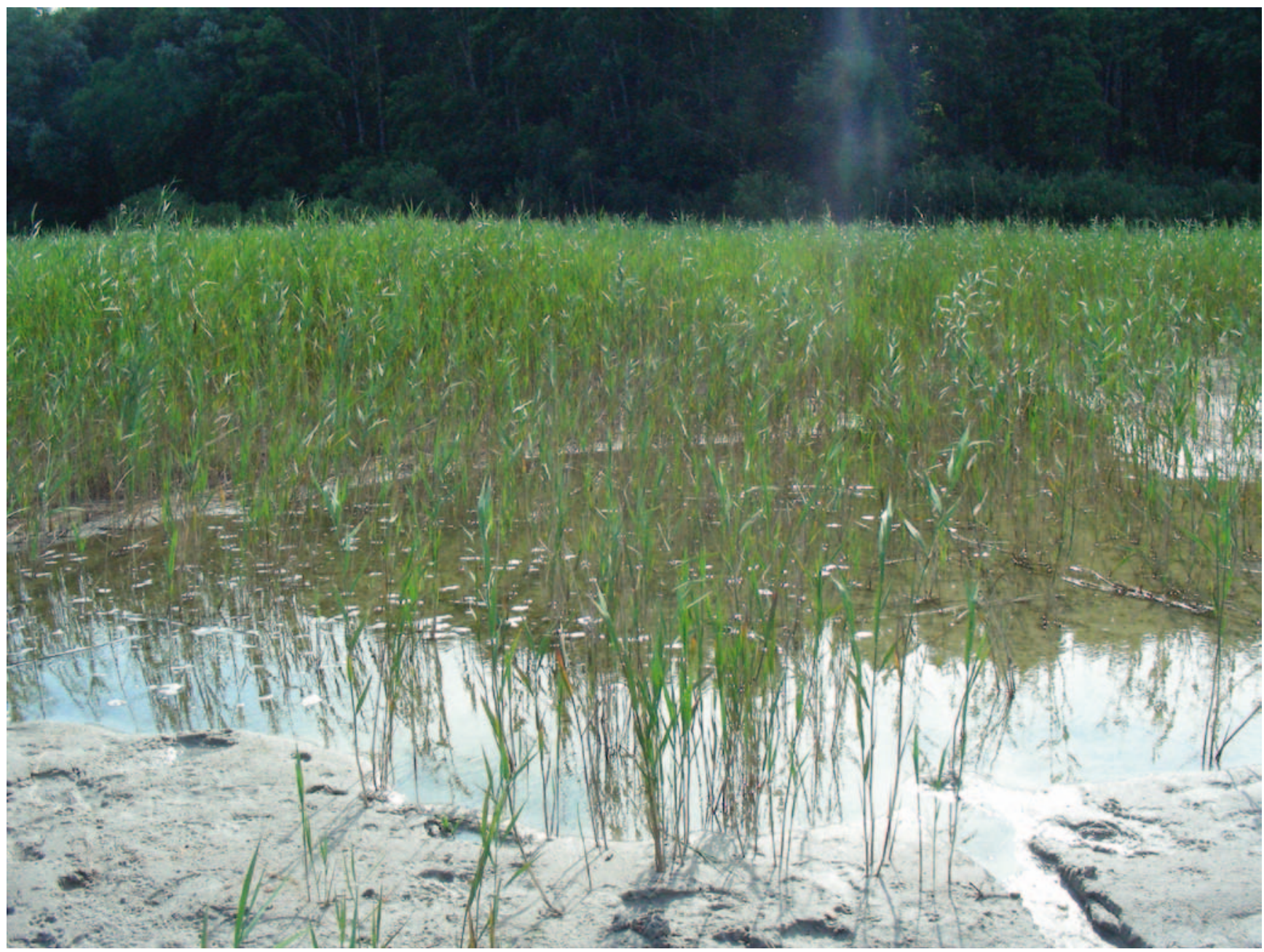

Fig. 4. Young common reed plants on the exposed shallows of Powidzkie Lake

Another factor, besides a reservoir's hydrology, that influences the development of riparian plants is the lake's morphology. Shallower, highly polluted lakes with a smaller volume were subject to faster riparian vegetation overgrowth as also documented in earlier publications on the topic (Kraska 2010). In the case of observations carried out on a single lake, it was noticed that zones of wide shallows were most exposed to vegetation expansion. In the case of reservoirs with a steep bottom in the littoral zone, on the other hand, expansion of vegetation towards the lake centre was sharply interrupted. The interruption was manifested by a sudden break in the community of tall, healthy and dense reeds along the line of the underwater slope. In comparison, shallow parts of the lake were covered by low density reed beds with short, thin and feeble plants (Fig. 4). The shape of a lake's shoreline was also a very important factor in the plant colonization process of riparian zones. It had an impact on both the quality of the new reed beds and the composition of species. Open zones, exposed to waves, were mostly populated by the common reed (Phragmites australis) or the common tule (Scirpetum lacustris), and, it might be added, these plants were for the most part in a much worse condition than those existing there before 1990. Shielded bays and arms exhibited a much bigger variety of plant species and generally healthier specimens. The most prominent species there, besides the common reed (Phragmites australis), were lesser bulrush (Typha angustifolia), common bulrush (Typha latifolia), common tule (Scirpetum lacustris), and on the lake side, floating-leaf plants of the genus Nymphaea. In the case of the almost total separation of a bay from the main basin, plants of the genus Carex and 
ferns composing the Caricion elatae community, and also, even though extremely rarely, of the Scheuchzerio-Caricatea fuscae class could be found (Fig. 5).

Reed bed status and its ability to invade a lake were also conditioned, to a large degree, by the availability of organic matter. It was noted that lakes poor in organic compounds host mostly the common reed (Phragmites australis). The reed beds of fertile lakes, on the other hand, are much richer in their species composition. The expansion of plants in highly eutrophicated lakes was much faster and the new growth was in a much better condition than in cleaner lakes. The process of vegetation encroachment, therefore, was correlated with the degree of lake pollution. Fast deterioration of water quality caused the acceleration of the plant encroachment process.

Land use, and especially increased inflow of pollution, was not without an influence on the ripar- ian plants. Reed beds that bordered agricultural land and tourist facilities, and especially reed beds that were close to drainage ditches and courses were noticeably larger and more diversified in comparison to reed beds in other parts of lakes. Similar observations are true for the lakes in the Lubuskie Region (Kraska 2010). An extreme example of riparian vegetation encroachment resulting, to a considerable degree, from land use and excess nutrient inflow is Biskupinskie Lake. One of its bays has been almost completely silted up and is now a habitat of exceptionally diversified scrub-shrub communities (Fig. 5). A factor that inhibited development of reed beds, on the other hand, was close proximity of coniferous forests. Other inhibiting factors included active beaches, boat and yacht marinas and regular cleaning of riparian zones.

An important factor conditioning reed bed development was also the bottom structure. We have es-

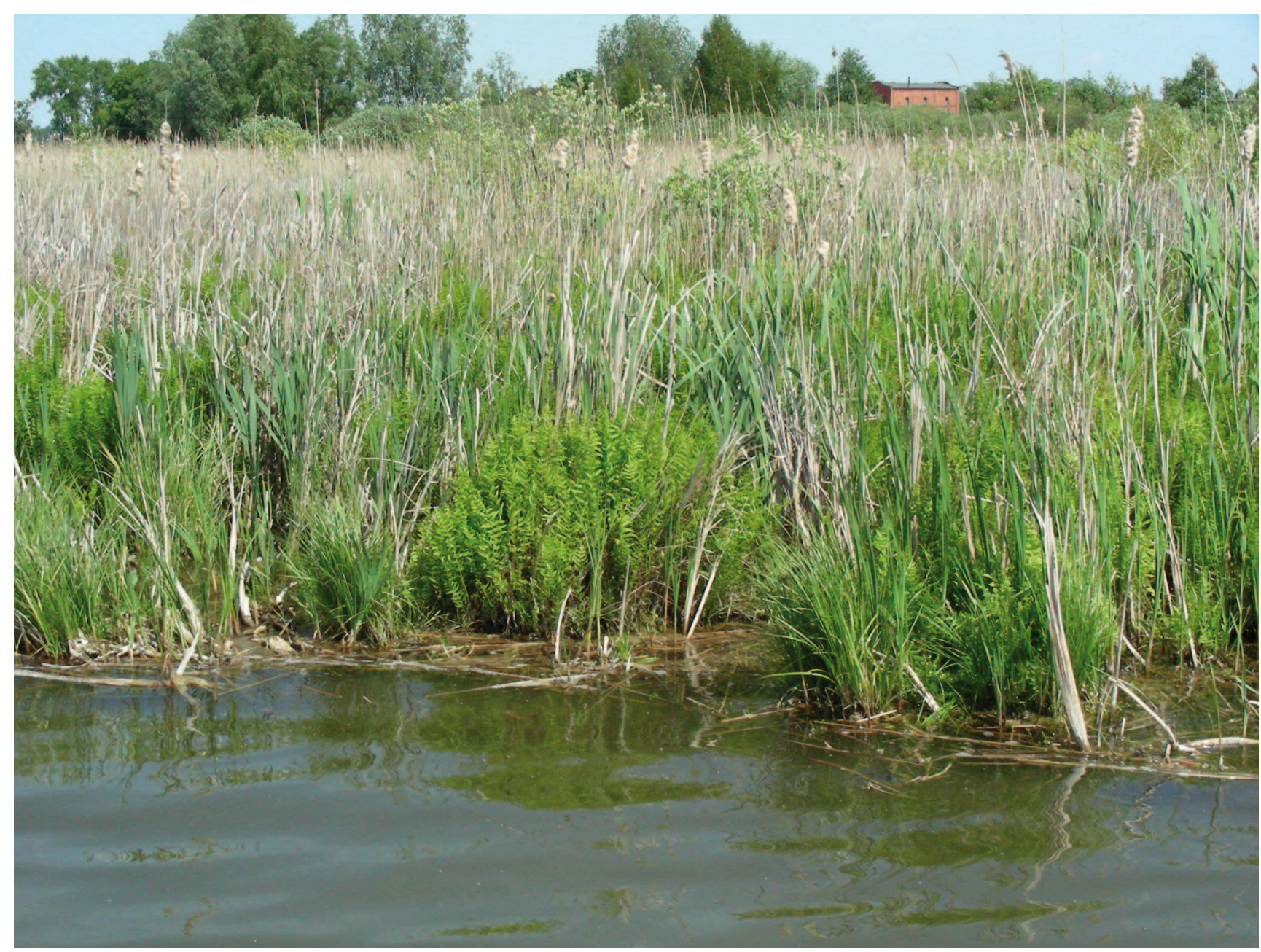

Fig. 5. Plant diversification of the scrub-shrub community in the cut off bay of Biskupińskie Lake 
tablished that a silted bottom was subject to a much faster plant colonization than a sandy bottom while a bottom covered with stones, or rather stones and sand, remained almost barren.

Observation of the shores of the Wielkopolska lakes allowed us to distinguish several patterns in the plant species composition of the reed beds. As mentioned earlier, plant species composition was determined, to a high degree, by the shape of shorelines. The in situ research allowed us to distinguish large differences in the development of reed bed zones within lakes, which can be classified into several categories. The first category consists of large, clean mesotrophic lakes where $95 \%$ of reed beds consist of mono-dominant stands of common reed (Phragmitetum australis). The second category includes medium size eutrophic lakes where common reed (Phragmites australis) constitutes $70-95 \%$ of plant growth complemented with Broadleaf Cattail (Typha latifolia) and Narrowleaf Cattail (Typha angustifolia), common tule (Scirpus lacustris), calamus (Acorus calamus), soft rush (Juncus effusus), common spike-rush (Eleocharis palustris), reed mannagrass (Glyceria maxima), and also, sporadically, sedges and ferns. The third and last category includes very shallow hypertrophic lakes where common reed (Phragmites australis) occupies over $70 \%$ of the area and does not form visible mono-dominant stands.

\section{Conclusion}

From the geological point of view, lakes are ephemeral entities with a life-span of between a few thousand to less than twenty thousand years on average. Lakes are naturally subject to shrinkage caused by processes of vegetation expansion and silting. Howev$\mathrm{er}$, in certain cases, the process of lake shrinkage takes much less time. Without question, smaller and shallower lakes are more vulnerable to riparian vegetation encroachment. Other key factors include the shape of the lake basin, the steep gradient of the lake bottom and lake shores, the type of lake (i.e. flow-through lake or lake with no inflows), and climate, especially temperature, wind speed and precipitation. Vegetation encroachment inward from the shorelines is also determined by the physiological capacity of plants living in riparian zones of fresh water reservoirs.

Vegetation colonization of riparian zones is therefore a very complex process determined by very many factors. The colonization process also leads to a considerable modification of the lake's riparian zone.
In some cases, overgrowth of riparian vegetation has negative effects from the human point of view. As shown, the excessive growth of riparian plants is a common occurrence in the Wielkopolska Lakeland and as such it has the potential to generate problems for self-governments and farmers using the lakes.

As a result of vegetation expansion onto riparian zones that used to be vegetation-free zones, the spawning grounds of fish, such as pike (Esox lucius), have been reduced. The structure of bottoms of lakes which had been silted up in zones colonized by reeds or hydrophytic plants has also been changed in many places. The reduced wave range weakened the sediment compaction process caused by wave base impact making parts of lakes hazardous for people, i.e. swimmers and wading anglers. In sites with particularly dense plant growth, water exchange with the open water zone has been reduced, thus increasing the lake's stagnation zones where the decomposition process is faster. Vegetation overgrowth combined with uninterrupted inflow of nutrients, stagnation in the reed bed zone and high temperatures can lead to the increased production of hydrogen sulphide. This can cause poisoning of people and animals in the proximity of such a zone. Lake Borowiec located in the KórnickoZaniemyskie lakes trough is an extreme example of such a development. As a result of an unprecedentedly fast vegetation expansion and high pollution, the lake has almost ceased to exist. at present, only a bog remains dissected by the slow Głuszyna River, once a popular paddling route. During the heat wave in summer 2009, the water flowing out of the lake turned white. The phenomenon was accompanied by a very pervasive stench. Several poisonings were also noted. The analysis carried out by the Institute of Meteorology and Water Management Poznan Branch [IMGW 2009] indicated that the source of the white colouring was hydrogen sulphide and colloidal sulphur precipitating from decaying organic matter accumulated in the plant covered and polluted Lake Borowiec.

Systematic vegetation encroachment of lakes leads to, as already mentioned, their shallowing. A higher volume of organic matter within the reservoir causes increased sedentation, i.e. precipitation of sediments in this particular case, plant detritus in the place of its origin. This results in the accelerated siltation of lakes.

The larger area of reed beds and other riparian plants contributes considerably to an increased evaporation rate from the lake surface (Nowak 2009, 2010). Evaporation from the lake surface is accompanied by 
plant transpiration (Leśny and Juszczak 2005) which increases the total evaporation even by several tens of percentage points. Consequently, the increased area occupied by the emergent plants leads to the reduction of water resources in a region.

Overgrowth of riparian plants, especially reed beds, does not have only negative socio-economic effects. Development of riparian plant communities also enriches wetland ecosystems. It increases the breeding area for animals, particularly rare and endangered amphibians and reptiles. The nesting grounds of many bird species are also enlarged. Vegetation encroachment into a lake, in some cases, also creates new niches for fish, thus providing better conditions for their development. An increased belt of riparian plants forms an additional protection against pollution, particularly excess nutrients, which are intercepted and stored in plant tissue. This, in turn, increases the selfpurification potential of reservoirs, especially the big ones with well developed shorelines.

Also, we need to keep in mind that the main component of reed beds, the common reed, is a precious material still used in building roofs of stylized houses, for instance. The larger area of reed beds combined with their good condition and huge capacity for restoration create, therefore, a possibility of development of this branch of economy without any harm to the environment. Regular mowing of reed has one more positive aspect. Mowing a stand allows organic substances stored in plant stems to be transported outside the reservoir, which is an effective and inexpensive way to clean the lake.

The process of vegetation encroachment has a considerable impact on human lives and the surrounding environment and as such it deserves a closer study. Its influence can be positive but it can also lead to some undesirable effects. For this reason, all processes occurring in this very vulnerable lake zone must be observed and resulting conclusions used to protect lakes and their shores.

\section{Acknowledgments}

Work completed within the research project DS. H - 3 'Transformations of lakes' riparian zones criteria of riparian plant succession and regression and its connection with changes of hydrometeorological and anthropogenic conditions" realized as a statutory task of the Institute of Meteorology and Water Management - National Research Institute

\section{References}

Dz.U.2005.239.2019, Ustawa z dnia 18 lipca 2001 r. - Prawo wodne, tekst jednolity (Act of 18 July 2001 - Water Law, consolidated text).

Grau J., Kremer B.P., Möseler B.M., Rambold G., Triebel D., 1998, Leksykon przyrodniczy. Trawy (Environmental Lexicon. Grasses), Świat Książki, Warszawa, p. 286 [in Polish].

[IMGW] Instytut Meteorologii i Gospodarki Wodnej w Poznaniu, 1981a, Mapa batymetryczna Jeziora Orchowskiego (Bathymetric map of Lake Orchowskie), IMGW Poznań, Poznań.

[IMGW] Instytut Meteorologii i Gospodarki Wodnej w Poznaniu, 1981b, Mapa batymetryczna Jeziora Słowikowo (Bathymetric map of Lake Słowikowo), IMGW Poznań, Poznań.

[IMGW] Instytut Meteorologii i Gospodarki Wodnej w Poznaniu, 1984a, Mapa batymetryczna Jeziora Jarosławieckiego (Bathymetric map of Lake Jarosławieckie), IMGW Poznań, Poznań.

[IMGW] Instytut Meteorologii i Gospodarki Wodnej w Poznaniu, 1984b, Mapa batymetryczna Jeziora Witobelskiego (Bathymetric map of Lake Witobelskie), IMGW Poznań, Poznań.

[IMGW] Instytut Meteorologii i Gospodarki Wodnej w Poznaniu, 2009, Analiza przyczyn występującego okresowo zwiększenia koncentracji zanieczyszczeń wód zanikającego Jeziora Borowieckiego i jego odpływu - rz. Głuszynki (Kopla) (Analysis of periodical water pollution accumulation in the disappearing Borowieckie Lake and its outflow - the Głuszynka River (Kopla)) [Manuscript], IMGW Poznań, Poznań, p. 54 [in Polish].

[IRS] Instytut Rybactwa Śródlądowego w Olsztynie, 1958a, Mapa batymetryczna Jeziora Biskupińskiego (Bathymetric map of Lake Biskupińskie), IRŚ, Olsztyn.

[IRS] Instytut Rybactwa Śródlądowego w Olsztynie, 1958b, Mapa batymetryczna Jeziora Chrzypskiego (Bathymetric map of Lake Chrzypskie), IRŚ, Olsztyn.

[IRS] Instytut Rybactwa Śródlądowego w Olsztynie, 1959, Mapa batymetryczna jeziora Lednica (Bathymetric map of Lake Lednica), IRŚ, Olsztyn.

[IRS] Instytut Rybactwa Śródlądowego w Olsztynie, 1960a, Mapa batymetryczna Jeziora Ostrowskiego (Bathymetric map of Lake Ostrowskie), IRŚ, Olsztyn.

[IRS] Instytut Rybactwa Śródlądowego w Olsztynie, 1960b, Mapa batymetryczna Jeziora Powidzkiego (Bathymetric map of Lake Powidzkie), IRŚ, Olsztyn.

[IRS] Instytut Rybactwa Śródlądowego w Olsztynie, 1962, Mapa batymetryczna Jeziora Lubikowskiego (Bathymetric map of Lake Lubikowskie), IRŚ, Olsztyn.

[IRS] Instytut Rybactwa Śródlądowego w Olsztynie, 1964, Mapa batymetryczna jeziora Konin (Bathymetric map of Lake Konin), IRŚ, Olsztyn.

[IRS] Instytut Rybactwa Śródlądowego w Olsztynie, 1968, Mapa batymetryczna Jeziora Kierskiego (Bathymetric map of Lake Kierskie), IRŚ, Olsztyn. 
Kłosowki S., Kłosowski G., 2006, Rośliny wodne i bagienne (Aquatic and wetland plants), Multico, Warszawa, $p$. 336 [in Polish].

Kondracki J., 2009, Geografia regionalna Polski (Regional geography of Poland), Wyd. Nauk. PWN, Warszawa, p. 468 [in Polish].

Kraska M., 2010, Roślinność wybranych jezior Pojezierza Lubuskiego i Pojezierza Sławskiego (Vegetation of selected lakes of the Lubuskie and Slawskie Lakelands), Wyd. Nauk. UAM, Poznań, p. 180 [in Polish].

Leśny J., Juszczak R., 2005, Oszacowanie ewapotranspiracji terenów znajdujących się w strefie bezpośredniego oddziaływania małych zbiorników wodnych krajobrazu rolniczego (Evaluation of evaporation of areas located within the zone of direct impact of small water reservoirs in agricultural landscape), Acta Agrophysica 6(1): 161-174 [in Polish].

Matuszkiewicz W., 2008, Przewodnik do oznaczania zbiorowisk roślinnych Polski (Guide to identification of plant communities of Poland), Wyd. Nauk. PWN, Warszawa, p. 538 [in Polish].

Nowak B., 2009, „Parowanie mechaniczne” z trzcinowisk na przykładzie Jeziora Powidzkiego ("Mechanical evaporation" from reed beds on the example of Powidzkie Lake), [in:] Marszelewski W. (ed.), Anthropogenic and natural transformations of lakes. vol. 3, PTLim, Toruń: 187-190 [in Polish, English summary].
Nowak B., 2010, Effect of rushes on evaporation rate in water reservoirs on the example of Powidzkie Lake, Limnol. Rev. 10(1): 37-41.

Rutkowski L., 2008, Klucz do oznaczania roślin naczyniowych Polski niżowej (Key to identification of vascular plants in lowland Poland), Wyd. Nauk. PWN, Warszawa, p. 814 [in Polish].

[WIOŚ] Wojewódzki Inspektorat Ochrony Środowiska w Poznaniu, 2011a, Raport o stanie środowiska w Wielkopolsce w roku 2010 (Report on the State of Environment in Wielkopolska in 2010), Bibl. Monit. Środ.,WIOŚ, Poznań, p. 70 [in Polish].

[WIOŚ] Wojewódzki Inspektorat Ochrony Środowiska w Bydgoszczy, 2011b, Raport o stanie środowiska województwa kujawsko-pomorskiego w 2010 roku (Report on the State of Environment in Kujawsko-Pomorskie Voivodeship in 2010), WIOŚ, Bydgoszcz, p. 234 [in Polish].

[WIOŚ] Wojewódzki Inspektorat Ochrony Środowiska w Zielonej Górze, 2011c, Stan środowiska w województwie lubuskim w latach 2009-2010 (State of the Environment in Lubuskie Voivodeship in the years 2009-2010), Bibl. Monit. Środ., WIOŚ, Zielona Góra, p. 146 [in Polish]. 